\title{
Study the Effect of Biofertilization and Cobalt on Growth and Productivity of Guar Plant under New Valley Conditions
}

\author{
A.M. Abd El-Gawad \\ Soil Fertility and Microbiology Departement, Desert Research \\ Center, Cairo, Egypt.
}

\begin{abstract}
TO INVESTIGATE the effect of biofertilization using Pseudomonas fluorescens and cobalt on growth and productivity of guar (Cyamposis tetragonoloba L.) under desert soil conditions. A field experiment was carried out for two successive seasons of 2010 and 2011 at the agriculture experimental station at El-Kharga Oasis, New Valley Governorate, Egypt. Bradyrhizobium spp. was used to inoculate seeds of all treatments and control as base application. Pseudomonas fluorescens was used as seed inoculant and cobalt at concentrations (5,10 and 20ppm) as foliar application in single and mixed treatment with Pseudomonas. Obtained results indicated that, interaction treatment between $P$. fluorescens inoculation and cobalt foliar application (20ppm) had the highest record for guar plant growth parameters, yield and its components as well as mineral contents of seeds (N,P,K as macronutrients) and ( $\mathrm{Zn}, \mathrm{Mn}, \mathrm{Fe}$ and $\mathrm{Cu}$ as micronutrient). Cobalt content in plant and seed, nodulation and its efficiency and microbial activity in guar rhizosphere.
\end{abstract}

Keywords: Guar, Cyamposis tetragonolba, Cobalt , Biofertilization, Pseudomonas fluorescens .

Guar (Cyamopsis tetragonoloba L.), is a member of the family fabaeace important summer season crop, It has good drought tolerant mechanism (Garg and Burman, 2002 and Tran, 2013) and ability to fix atmospheric nitrogen (Ahmad, 2008).

Guar is a promising summer forage crop that could be used in Egypt to reduce the gap between the available and required summer forage crops for livestocks feeding especially in grass-legume mixtures to increase dry matter yield and give forage of better quality than pure crop (Farag and Abd El-lateef, 1997 and Khalid et al., 2010). Also, guar has been well grown in wide range of soils. The most excellent performance by the fertile medium to light sandy loam soil with $\mathrm{pH}$ values of 7.5 to 8 (Francois et al., 1990).

Guar (clusterbean) is a rich source of high quality galactomannan gum which is in great demand in the world market because of it multi-purpose use in textiles, foods, cosmetics, mining, explosives and oil industries. Despite multipurpose use of clusterbean, no systematic work has been done to improve the nodulation, nitrogen-fixing ability and crop productivity using bioinoculants. Thus, it is 
desired that efficient Rhizobium/Bradyrhizobium cultures should be isolated and introduced in clusterbean growing areas to improve its nodulation status, seed quality and crop productivity (El-Sheikh and Ibrahim, 1999).

In sustainable agriculture, different soil microorganisms with beneficial characteristics were used as bioinoculants to improve productivity of cereal and legume crops, while minimizing the application of chemical fertilizers (Welbaum et al., 2004 and Compant et al., 2010). Among bioinoculants, nitrogen-fixing microorganisms offer an ecofriendly alternative to nitrogenous fertilizers in farming practices and supply fixed $\mathrm{N}$ to crop plants resulting in improved crop production (Burris and Roberts, 1993 and Sindhu et al., 2010). Some plant growth-growth promoting rhizobacteria (PGPR) promote growth of cereals and legumes by solubilizing bound phosphorus(Sindhu et al., 2009) and potassium (Basak and Biswas, 2008 and Parmar \& Sindhu, 2013) and by release of vitamins, auxins and plant growth regulating substances(Lugtenberg and Kamilova, 2009 and Jangu \& Sindhu, 2011). PGPR have also been found to suppress plant diseases caused by potential pathogens by production of antibiotics, siderophores, hydrocyanic acid and/or hydrolytic enzymes (Stockwell and Stack, 2007 and Dua \& Sindhu, 2012).

Bradyrhizobium inoculation to guar significantly improved nodulation and dry matter production particularly by locally isolated bradyrhizobia. Nitrogen fertilization improved dry matter production but depressed nodulation. Phosphate mitigated the depressive effect of nitrogen on nodulation and further enhanced its stimulatory effect on dry matter production (Gadallah et al., 2010). Inoculation of guar with Rhizobium on sandy loam soil elevated seed yield, seed gum and protein content Brokwell and Bottmely (1995). Nodulation in some legumes under field conditions is very poor, it may be due to absence of Rhizobium in such soils. Alternatively other environmental factors such as salinity, high temperature and draught may affect the nodulation and nitrogen fixation of leguminous plants (El-Sayed, 1997).

Andrade et al. (1998) found that Pseudomonas fluorescens enhanced nodulation by Rhizobium fourfold, While nodule produced were much larger and strongly pigmented (pink) as compared to those in other treatments. Myer and Linderman (1986) showed that Pseudomonas putida a siderophore producing plant growth promoting rhizobacterium, enhanced nodulation and nitrogen fixation by Rhizobium. The mechanism postulated was that effective scavenging for iron by this strain reduced populations of microorganisms that were deletrious to rhizobium while simultaneously providing the plant with extra iron.Similarly, Staley et al. (1992) showed that this strain increased nodulation on alfalfa. Cobalt is an essential element for legumes because of its use by microorganisms in fixing atmospheric nitrogen (Evan and kliwer, 1964). Bacteria on root nodules of legumes (Beans, alfalfa and clover) required cobalt to synthesize vitamin B12 and fix nitrogen from air (Young, 1983). Meanwhile Nasef et al. (2008) found that cobalt showed significantly higher nodule number and weight, nodule $\mathrm{N}$ concentration, leghaemoglobin content, total biomass production and seeds yield

Egypt. J. Soil Sci. 53, No. 4 (2013) 
compared with untreated plants. Recently, Vijayarengan et al. (2009), Jayakumar et al. (2009) and Kaliyamoorthy et al. (2013) showed that cobalt application at $50 \mathrm{mg} / \mathrm{kg}$ soil had a beneficial effect on biochemical contents, i.e., sugar, protein and amino acids of groundnut seeds compared with control plants.

The biological importance of cobalt was first recognized by the discovery that small amounts of the element would certain deficiency symptoms in plants (Jayakumar and Vijayarengan, 2006). In abiotic stress, metal response will result in the production of reactive oxygen species (ROS) which leads to the activation of defense mechanisms in terms of antioxidant enzymes.

This study was conducted to investigate the effect of Biofertilization and cobalt foliar application on growth and productivity of guar(Cyamposis tetragonoloba L.) cultivated in El-Kharga Oasis, New Valley Governorate, Egypt.

\section{Material and Methods}

The present investigation were carried out during the two successive seasons of 2010 and 2011 in newly cultivated lands under sandy soil conditions at the Agriculture Experimental Station at El-Kharga Oasis (30.53 longitude, 24.45 latitude and elevation78.8), New Valley Governorate, Desert Research Center (DRC),to investigate the effect of Biofertilization and Cobalt on growth and productivity of Guar (Cyamopsis tetragonoloba . L).

Guar (Cyamopsis tetragonoloba. L) seeds obtained from Agriculture Research Center, Ministry of Agriculture, Giza, Egypt were sown in May 2010 and May 2011 in plots $(3-3.5 \mathrm{~m})$ in rows. The mineral fertilization was applied as a general application. Calcium super phosphate $31 \mathrm{kgP}_{2} \mathrm{O}_{5} / \mathrm{fed}$ was mixed with soil before sowing, $\mathrm{N}$ and $\mathrm{K}$ fertilizers were added at a rate of $60 \mathrm{~kg} / \mathrm{fed}$ as $\mathrm{NH}_{4} \mathrm{NO}_{3}$ and $75 \mathrm{~kg}$ $\mathrm{K}_{2} \mathrm{O} /$ fed as $\mathrm{K}_{2} \mathrm{SO}_{4}$ into three split equal doses applied after 30,60,90 days. Sheep manure were applied at the rate of $20 \mathrm{~m}^{3} /$ feddan as organic manure containing O.C $\% 28, \mathrm{~N} \%$ 2.41,C/N ratio11.62 and O.M\% 48.16. The physical and chemical analysis of soil and irrigation water were presented in Tables 1 and 2.

TABLE 1. Some physical and chemical properties of the experimental soil.

\begin{tabular}{|c|c|c|c|c|c|c|c|c|c|c|}
\hline \multicolumn{11}{|c|}{ Mechanical analysis } \\
\hline \multicolumn{3}{|c|}{ Sand } & \multicolumn{3}{|c|}{ Clay } & \multicolumn{2}{|c|}{ Silt } & \multicolumn{3}{|c|}{ Soil Texture } \\
\hline \multicolumn{3}{|c|}{$50.8 \%$} & \multicolumn{3}{|c|}{$30.9 \%$} & \multicolumn{2}{|c|}{$18.3 \%$} & \multicolumn{3}{|c|}{ Sandy clay loam } \\
\hline \multicolumn{11}{|c|}{ Chemical analysis } \\
\hline \multirow[t]{2}{*}{ pH } & \multirow{2}{*}{$\begin{array}{c}\text { EC } \\
\text { ds/m }\end{array}$} & \multirow[t]{2}{*}{$\overline{T \text { T.N }}$} & \multicolumn{4}{|c|}{ Cations (meq/L) } & \multicolumn{4}{|c|}{ "Anions (meq/L) } \\
\hline & & & $\mathrm{Ca}^{+2}$ & $\mathrm{Mg}^{+2}$ & $\overline{\overline{\mathbf{K}^{+}}}$ & $\mathrm{Na}^{+}$ & $\mathrm{CO}_{3}{ }^{-2}$ & $\mathrm{HCO}^{-3}$ & $\mathrm{Cl}^{-}$ & $\mathrm{SO}_{4}{ }^{-2}$ \\
\hline 8.8 & 4.56 & $92 \mathrm{ppm}$ & 8.76 & 4.68 & 1.26 & 29.44 & 0.00 & 8.96 & 13.52 & 21.66 \\
\hline \multicolumn{11}{|c|}{ Trace elements (mg/l) } \\
\hline \multicolumn{2}{|c|}{ Zn } & \multicolumn{2}{|c|}{ Mn } & \multicolumn{2}{|c|}{$\mathbf{C u}$} & \multicolumn{2}{|c|}{$\mathbf{F e}$} & B & & Co \\
\hline \multicolumn{2}{|c|}{5.744} & \multicolumn{2}{|c|}{4.69} & \multicolumn{2}{|c|}{1.77} & \multicolumn{2}{|c|}{33.48} & 0.49 & \multicolumn{2}{|r|}{0.03} \\
\hline
\end{tabular}


TABLE 2. Chemical analysis of irrigation water.

\begin{tabular}{|c|c|c|c|c|c|c|c|c|c|}
\hline \multirow{3}{*}{ pH } & \multirow{3}{*}{$\begin{array}{l}\text { E.C } \\
\text { ds } / \mathbf{m}\end{array}$} & \multicolumn{8}{|c|}{ Soluble ions (meq/L) } \\
\hline & & \multicolumn{4}{|c|}{ Cations } & \multicolumn{4}{|c|}{ Anions } \\
\hline & & $\overline{\mathrm{Ca}^{+2}}$ & $\overline{\mathrm{Mg}^{+2}}$ & $\mathrm{Na}^{+}$ & $\overline{\mathbf{K}^{+}}$ & $\mathrm{CO}_{3}{ }^{-2}$ & $\mathrm{HCO}_{3}^{-}$ & $\overline{\mathrm{Cl}^{-}}$ & $\overline{\mathrm{SO}_{4}^{-2}}$ \\
\hline$\overline{7.2}$ & $\overline{0.814}$ & 3.92 & 1.96 & 3.3 & 0.184 & 0.8 & 5.36 & 2.28 & 1.23 \\
\hline
\end{tabular}

Isolation, purification and selection of pseuomonas isolates

Different soil samples were collected from different sites of El-Kharga Oasis, New valley used for isolation,7 Pseudomonas isolates were obtained as shown in Table 3. Cultures of Pseudomonas isolates were purified by successive streaking on King's medium B is based on the formulation of Murray et al. (2003). Microscopical examination was carried out to check the purity of cultures. The purified 7 Pseudomonas isolates were tested for their phosphate dissolving efficiency quantitative and qualitative according to deFreitas et al. (1997), siderophore production (Reeves, 1983) and salycilic acid production (Meyer et al., 1992).

TABLE 3. Phosphate solubilization,Siderophore and Salicylic acid production by Pseudomonas isolates.

\begin{tabular}{|c|c|c|c|c|}
\hline \multirow[b]{2}{*}{$\begin{array}{l}\text { Pseudomonas } \\
\text { isolates }\end{array}$} & \multicolumn{2}{|c|}{ Phosphate solubilization } & \multirow[b]{2}{*}{$\begin{array}{c}\text { Siderophores } \\
\text { ( } \mu \mathrm{g} / \mathrm{ml}, \mathbf{4 1 0} \\
\mathrm{nm})\end{array}$} & \multirow[b]{2}{*}{$\begin{array}{c}\mathrm{SA} \\
(\mu \mathrm{g} / \mathrm{ml}, \\
527 \mathrm{~nm})\end{array}$} \\
\hline & $\begin{array}{c}\text { Mean } \\
\text { diameter } \\
\text { of lysis } \\
\text { (cm) }\end{array}$ & $\begin{array}{c}\text { Phosphorus } \\
\text { concentration } \\
\mathrm{mg} / \mathrm{l}\end{array}$ & & \\
\hline 1 & 0.9 & 1.5 & 31.9 & 36 \\
\hline 2 & 1.1 & 2.5 & 42 & 23.7 \\
\hline 3 & 0.6 & 1.4 & 38.1 & 20.1 \\
\hline 4 & 2.3 & 4.8 & 59.73 & 39.4 \\
\hline 5 & 1 & 1.7 & 40.5 & 28 \\
\hline 6 & 1.5 & 2.9 & 46 & 41.9 \\
\hline 7 & 0.8 & 1.6 & 54 & 33 \\
\hline
\end{tabular}

\section{Identification of Pseuomonas isolate}

The most active fluorescent Pseudomonas isolates with phosphate dissolving activity, siderophore production and Salycilic acid production were identified using Bergey's Manual of determinative bacteriology (1984 and 1994) (Table 4).

Bradyrhizobium spp.

Locally isolated Bradyrhizobium spp. were maintained at $4{ }^{\circ} \mathrm{C}$ on yeast extract mannitol agar(YEMA). 
TABLE 4. Identification of Pseudomonas isolate no.4.

\begin{tabular}{|l|c|c|c|}
\hline \multicolumn{1}{|c|}{ Biochemical reactions } & Results & Biochemical reactions & Results \\
\hline Morphological character: & Short rod & Catalase production & Lipase (Tween 80 \\
Shape & Motile & hydrolysis) & + \\
Motility & Gram -ve & Utilization of : & \\
Gram reaction & + & Glucose & + \\
KOH solubility test & & Trehalose & - \\
Physiological character : & + & L-Rhamnose & - \\
Pyoverdin production & + & D-Mannose & + \\
Pyocyanin production & + & D-Galactose & + \\
Oxidase reaction & + & Mannitol & + \\
Gelatin liquefaction & - & L-Tryptophan & + \\
Starch hydrolysis & + & D-Alanine & + \\
Hydrogen sulphide production & & & + \\
& \multicolumn{2}{|r}{} \\
\hline
\end{tabular}

Biochemical activities of studied microbial isolate

The ability of the tested microbial isolates to produce biochemical activities was evaluated under in vitro conditions, through determination of their efficiency for growth regulators production (Rizzolo et al., 1993), nitrogen fixation (Page et al., 1982), enzymes (Barrow and Velthan, 1993), antibiotics production (Jarlier et al., 1996) (Table 5).

TABLE 5. Biochemical activities of microbial isolates.

\begin{tabular}{|c|c|c|c|c|c|}
\hline & $\begin{array}{c}\boldsymbol{P} . \\
\text { fluore- } \\
\text { scens }\end{array}$ & $\begin{array}{c}\text { Bradyrhiz- } \\
\text { obium }\end{array}$ & $\begin{array}{c}\boldsymbol{P} . \\
\text { fluore- } \\
\text { scens }\end{array}$ & $\begin{array}{c}\text { Bradyrhiz- } \\
\text { obium }\end{array}$ \\
\hline Nitrogenase & - & 395 & $\begin{array}{c}\text { Hormonal } \\
\text { activity } \mu \mathrm{g} / \mathrm{ml}\end{array}$ & & \\
$\left(\mu \mathrm{lC}_{2} \mathrm{H}_{4} \mathrm{H}^{-1} \mathrm{I}^{-1}\right)$ & & & IAA & 9.4 & 2.7 \\
& & & GA3 & 2.48 & 3.29 \\
& & & Cytokinine & 23.67 & 12.4 \\
\hline Enzyme & & & Antibiotic & & \\
activity: & & & roduction(mm) & & \\
Amylase & - & + & E.coli & 28 & - \\
Cellulase & + & + & Salmonella typhi & 21 & - \\
Protease & + & + & F.oxysporum & 35 & - \\
Pectinase & + & + & R.solani & 29 & - \\
\hline
\end{tabular}

\section{Purification and maintenance of Cultures}

Pseudonomonas fluorescens and Bradyrhizobium spp., were isolated and purified by streak plate method on king's B medium and Yeast Extract Mannitol Agar medium respectively. Individual colonies were streaked on respective slants and stored in a refrigerator at $4^{\circ} \mathrm{C}$ for further studies. 
The inoculum of each strain was prepared by growing them in $500 \mathrm{ml}$ flasks containing selective media, flasks incubated at $30^{\circ} \mathrm{C}$ for $48 \mathrm{hr}$ under shaking, the suspension containing $10^{8} \mathrm{cfu} / \mathrm{ml}$ used for inoculation.

Compatibility test of the inoculants

Bradyrhizobium spp. and Pseudomonas fluorescens were tested for compatibility of growth by cross streak assay in nutrient agar medium. Nutrient agar medium was prepared and sterilized. The medium was poured into sterile petri plates and allowed for solidification. To test the compatibility of $P$. fluorescens with Bradyrhizobium spp. P. fluorescens was streaked as a strip at one end of the plate and incubated for $24 \mathrm{hr}$ to form a thick growth. The test cultures of Bradyrhizobium spp. was streaked perpendicular to P.fluorescens growth. The plates were incubated for $48 \mathrm{hr}$ and observed for the growth of Bradyrhizobium spp. and $P$. fluorescens.

Seeds of all the experimental plots inoculated with Bradyrhizobium spp. as base application (Seeds of guar were washed and immersed for $30 \mathrm{~min}$ in liquid culture of Bradyrhizobium spp.to be tested. Carboxymethyl cellulose (CMC $0.5 \%$ ) was used as an adhesive agent. Seeds were then dried at room temperature for two hours.

The concentration of cobalt were used as foliar spray (5,10 and $20 \mathrm{ppm})$ alone and in combination with Pseudomonas fluorescens inoculation.

The experiment included 8 treatments where Bradyrhizobium used as base treatments:
1- control(Bradyrhizobium).
2- Pseudomonas.
3- Co 5ppm.
4-Co 10ppm.
5- Co 2ppm.
6- Pseudomonas+ Co 5 ppm
7- Pseudomonas+Co 10ppm.
8- Pseudomonas +Co 20ppm.

After 45 days, the soil samples were taken for nodulation testing. At 60 days old, three replicates were left for determination of guar growth parameters, yield and its components as follow: Plant height $(\mathrm{cm})$, fresh weight and dry matter \%, the nitrogen \% according to Page et al. (1982), protein content calculated by multiplying $\mathrm{N} \%$ by 6.25 , , phosphorus, potassium and micronutrients were determined (colorimetric method) in seed according to Cottenie et al. (1982).

Rhizosphere soil samples were collected and analyzed for determination of total microbial counts on Bunt and Rovira medium (Nautiyal, 1999). $\mathrm{CO}_{2}$ evolution according to Anderson (1982) and Estimates of number of Pseudomonas by MPN technique were calculated using Garthright (1993). Nodulation (nodule number and dry weight of nodule), the leg-haemoglobin content of root nodules were analyzed by the method of Wilson and Reiesenauer (1963), Nitrogenase activity was determined according to Haahtela et al. (1981).

Egypt. J. Soil Sci. 53, No. 4 (2013) 
Plants and seed were analyzed for Co concentration by Atomic Absorption spectrophotometer (Miller, 1998 and Malik \& Teuswal, 2000). The completely randomized block design was used for statistical analysis of the subjected obtained data. The combined analysis of data, for the two seasons was conducted and the difference between means of various treatments had done by using L.S.D. at 5\% significant level according to Snedecor and Cochran (1990).

\section{Results and Discussion}

Isolation and selection of pseuomonas isolates

A number of 7 Pseudomonas isolates were isolated (Table 3), purified and examined for their activities to dissolve phosphate qualitative (deFreitas et al., 1997) and quantitative (Schinner et al., 1996), production of siderophore (Reeves, 1983) and production of salicylic acid (Meyer et al., 1992).

\section{Identification of Pseudomonas isolate}

The most active isolate no. (4) was completely identified according to Bergey's Manual of determinative bacteriology (1984 and 1994). The morphological and physiological characters presented in Table 4. Selected Pseudomonas isolate was found to belong to $P$. fluorescens.

Biochemical activities of Pseudomonas fluorescens and Bradyrhizobium spp.

Microbes under study known to produce a number of secondary metabolites (Table 5) which may affect growth, health of plants, and the relationships between rhizosphere soil microorganisms. Plant growth regulators (quantitative (HPLC) $/ \mu \mathrm{g} / \mathrm{ml}$ ),nitrogen fixation, enzyme and antibiotic production. Also, Table 5 showed the biochemical activities of the Bradyrhizobium spp. and Pseudomonas fluorescens used in the trial for production of plant hormones, antibiotics, enzymes and nitrogen fixation. As shown in Table 5 the microorganisms exhibited biochemical and hormonal activities in vitro that could result in beneficial action in field (Aml and Abd El-Hai, 2011).

\section{Compatibility test of the inoculants}

Bradyrhizobium spp. and P. fluorescens were found to be compatible with each other and were able to grow simultaneously without and inhibition in growth.

Effect of Biofertilization and Cobalt on growth parameters of Guar

The obtained results in Table 6 reported that, in the presence of Bradyrhizobium spp. as base treatment, inoculation with $P$. fluorescens and cobalt applications increased plant height, fresh weight and dry matter \% higher than individual treatments with cobalt or $P$. fluorescens application through first, second cuts, harvesting stage and for the first cut during the two growing seasons.

Plant growth promoting $P$. fluorescens induced positive response on growth and physiological parameters through production of 2,4-diacetylphloroglucinol which increase root length, root weight, transiently enhanced lateral root 
formation, thickening of leaf palisade layer, spreading of lateral roots and production of root hairs. The growth and yield parameters were significantly improved as compared with the control (Boruah et al., 2003).

TABLE 6. Effect of biofertilization and Cobalt on growth parameters of Guar.

\begin{tabular}{|c|c|c|c|c|c|c|c|c|c|}
\hline \multirow{3}{*}{ Treatments } & \multicolumn{9}{|c|}{$\mathbf{1}^{\text {st }}$ season } \\
\hline & \multicolumn{3}{|c|}{ Plant height (cm) } & \multicolumn{3}{|c|}{ F.W kg/f } & \multicolumn{3}{|c|}{ D.M\% } \\
\hline & $\mathbf{1}^{s t}$ cut & $2^{\text {nd }}$ cut & Harv. & $\mathbf{1}^{\text {st }}$ cut & $2^{\text {nd }}$ cut & Harv. & $1^{s t}$ cut & $2^{\text {nd }}$ cut & Harv. \\
\hline Control & 100 & 98 & 93 & 1250 & 1244 & 1239 & 20.12 & 17.61 & 17.43 \\
\hline$P s$ & 107 & 105 & 101 & 1280 & 1251 & 1247 & 22.2 & 18 & 16.52 \\
\hline Co 5ppm & 109 & 106 & 97 & 1286 & 1258 & 1251 & 24.1 & 19.1 & 17.81 \\
\hline Co 10ppm & 113 & 108 & 103 & 1290 & 1283 & 1269 & 27.2 & 23.6 & 20.4 \\
\hline Co 20ppm & 120 & 117 & 115 & 1297 & 1289 & 1280 & 27.6 & 24.1 & 21.6 \\
\hline Ps+Co5ppm & 127 & 120 & 118 & 1303 & 1294 & 1286 & 28.2 & 24.8 & 22 \\
\hline Ps+Co10ppm & 132 & 126 & 122 & 1308 & 1302 & 1291 & 29 & 26.3 & 22.5 \\
\hline Ps+Co20ppm & 135 & 129 & 124 & 1321 & 1317 & 1310 & 29.6 & 27.1 & 24.3 \\
\hline $\begin{array}{l}\text { L.S.D at 5\%: Bio } \\
\text { Cut } \\
\text { Interaction }\end{array}$ & \multicolumn{3}{|c|}{$\begin{array}{l}1.8763 \\
1.68 \\
1.018\end{array}$} & \multicolumn{3}{|c|}{$\begin{array}{c}1.125 \\
1.00531 \\
0.61563\end{array}$} & \multicolumn{3}{|c|}{$\begin{array}{c}0.35362 \\
0.216549 \\
1.90795 \\
\end{array}$} \\
\hline \multicolumn{10}{|c|}{$2^{\text {nd }}$ season } \\
\hline Control & 104 & 97 & 93 & 1252 & 1247 & 1243 & 20.46 & 18.1 & 17.93 \\
\hline$P s$ & 108 & 105 & 98 & 1287 & 1273 & 1256 & 24.39 & 22.8 & 19.25 \\
\hline Co 5ppm & 111 & 106 & 102 & 1298 & 1292 & 1281 & 25.81 & 23.72 & 20.11 \\
\hline Co 10ppm & 117 & 112 & 105 & 1309 & 1298 & 1288 & 26.92 & 24.18 & 21.93 \\
\hline Co 20ppm & 122 & 119 & 110 & 1316 & 1311 & 1297 & 27.55 & 24.66 & 22.5 \\
\hline Ps+Co5ppm & 129 & 123 & 116 & 1321 & 1314 & 1308 & 28.4 & 25.81 & 24.26 \\
\hline Ps+Co10ppm & 133 & 128 & 121 & 1329 & 1319 & 1316 & 29.98 & 26.1 & 24.7 \\
\hline Ps+Co20ppm & 141 & 132 & 127 & 1328 & 1322 & 1318 & 30.1 & 27.9 & 26.5 \\
\hline $\begin{array}{r}\text { L.S.D at 5\%:Bio } \\
\text { Cut } \\
\text { Interaction }\end{array}$ & \multicolumn{3}{|c|}{$\begin{array}{c}0.59633 \\
1.0556\end{array}$} & & $\begin{array}{l}1.3996 \\
0.8571 \\
2.1801\end{array}$ & & \multicolumn{2}{|r|}{0.041501} & \\
\hline
\end{tabular}

F.W: fresh weight. $\quad$ Co: Cobalt. $\quad$ Ps: Pseudomonas fluorescens. $\quad$ DM: Dry matter of plant.

The enhancement effect due to cobalt application on development process including growth parameters as stem cleoptile elongation, leaf expansion, bud development and shoot dry weight (Nadia Gad, 2006).

The highest $\%$ of increase than control in plant height, fresh weight $(\mathrm{kg} / \mathrm{fed})$ and Dry matter \% recorded with interaction treatment between P. fluorescens inoculation and cobalt 20ppm foliar application during two cuts and harvesting stage being $35 \%, 32 \%$ and $34 \% \mathrm{~cm}$ in first growth season and $36 \%, 36.1 \%$ and $37 \%$ in second growth season for plant height respectively. 57\%, 59\% and 57\% in first growth season and $61 \%, 60 \%$ and $60 \%$ in second growth season for fresh weight, respectively. Also, highest dry matter $\%$ were 47,54 and $39 \%$ in first growth season and 47, 54 and $48 \%$ in second growth season, respectively. Data at second growing season were higher than that of first growth season. These results are in line with (Ayub et al., 2012 and Gomaa \& Magda, 2007), interaction application of $P$. fluorescens inoculation and cobalt $20 \mathrm{ppm}$ foliar application resulted in synergistic effect.

Egypt. J. Soil Sci. 53, No. 4 (2013) 
Effect of biofertilization and Cobalt on Guar yield and its components

The impact of various tested treatments on number of pods/plant, No.seeds/pod, No. seed/plant, 100 seed weight and seed yield as compared with control (Bradyrhizobium spp. as application treatment) during two growth season was demonstrated in Table 7.

TABLE 7. Effect of biofertilization and Cobalt on yield of Guar.

\begin{tabular}{|l|c|c|c|c|c|c|}
\hline \multirow{2}{*}{ Treatments } & \multicolumn{7}{|c|}{$\mathbf{1}^{\text {st }}$ season } \\
\cline { 2 - 7 } & $\begin{array}{c}\text { No. } \\
\text { Pod/Plant }\end{array}$ & $\begin{array}{c}\text { No.seed/ } \\
\text { pod }\end{array}$ & $\begin{array}{c}\text { No.seed/ } \\
\text { plant }\end{array}$ & $\begin{array}{c}\mathbf{1 0 0} \text { seed wt } \\
\text { gm }\end{array}$ & $\begin{array}{c}\text { Seed yield } \\
\text { kg/f }\end{array}$ & $\begin{array}{c}\text { Protein \% } \\
\text { in seeds }\end{array}$ \\
\hline Control & 15.3 & 5.4 & 86 & 3.11 & 450 & 23.75 \\
\hline$P s$ & 17.6 & 6.3 & 109 & 3.42 & 472 & 24.5 \\
\hline Co 5ppm & 18.1 & 6.8 & 116 & 3.45 & 479 & 25.38 \\
\hline Co 10ppm & 18.2 & 7.4 & 139 & 3.59 & 516 & 25.94 \\
\hline Co 20ppm & 18.9 & 7.9 & 154 & 3.84 & 548 & 26.25 \\
\hline Ps+Co5ppm & 21.62 & 8 & 183 & 4.35 & 580 & 27.3 \\
\hline Ps+Co10ppm & 22.3 & 8.6 & 192 & 4.42 & 594 & 28.1 \\
\hline Ps+Co20ppm & 24 & 10.2 & 196 & 4.94 & 619 & 29.4 \\
\hline L.S.D at 5\% & 0.63403 & 0.1731 & 1.731 & 0.018696 & 1.7311 & 0.37499 \\
\hline & \multicolumn{7}{|c|}{$\mathbf{2}^{\text {ndd }}$ season } & & & \\
\hline Control & 15.7 & 5.5 & 91 & 3.19 & 463 & 24.5 \\
\hline Ps & 17.85 & 7.2 & 123 & 3.61 & 481 & 27.25 \\
\hline Co 5ppm & 18.3 & 8 & 138 & 3.84 & 490 & 26.4 \\
\hline Co 10ppm & 19 & 8.4 & 154 & 4.13 & 534 & 27.3 \\
\hline Co 20ppm & 22 & 9 & 167 & 4.29 & 556 & 27.44 \\
\hline Ps+Co5ppm & 23.8 & 9.3 & 189 & 4.37 & 583 & 28 \\
\hline Ps+Co10ppm & 24.6 & 9.8 & 194 & 4.72 & 608 & 29.1 \\
\hline Ps+Co20ppm & 24.9 & 11.3 & 201 & 5.26 & 630 & 30.2 \\
\hline L.S.D at 5\% & 0.63894 & 0.65053 & 1.730895 & 0.01731 & 2.44786 & 0.65996 \\
\hline
\end{tabular}

Co: Cobalt. Ps: Pseudomonas fluorescens .

Obviously inoculation with $P$. fluorescens and cobalt 20ppm foliar application gave the highest record for tested yield components. Biofertilization proved to be effective in increasing the yield of guar for No.pods/plant, No.seeds/pod and No.of seeds/plant, the highest values being 24,10.2 and 196 in first growing season and 24.9, 11.3 and 201 in the second growing season respectively. 100 seed weight $(\mathrm{gm})$ and seed yield $(\mathrm{kg} / \mathrm{fed})$ being 4.94and $619 \mathrm{~kg} / \mathrm{fed}$ in the first growing season and $5.26 \mathrm{gm}$ and $630 \mathrm{~kg} / \mathrm{fed}$ in second growing season, respectively. Obtained trend for protein $\%$ which was $29.4 \%$ and $30.2 \%$ in first and second growing season, respectively. The obtained results were found to be on the same line with those obtained by Gaballah and Gomaa (2005) and Mohamed \& Gomaa (2005) they reported that, plant growth promoting rhizobacteria (PGPR) proved to be effective in increasing the yield of guar through production of amino acids like niacin and pantothenic acid, it also produced different other vitamins such as biotin, thiamine, cobalamine and pyridoxine. Cobalt application strongly influenced protein $\%$, production of four new polypeptides and induction of antioxidant enzyme ( Peroxidase, catalase, polyphenoloxidase, Ascorbic acid, glutathione, a-tocopherol and cartenoid) in cluster bean (Gurusaravanan et al., 2012 and Kaliyamoorthy et al., 2013). 
Effect of biofertilization and Cobalt application on some minerals contents of seeds.

As demonstrated in Table 8 in the presence of Bradyrhizobium spp. as a base application, inoculation with $P$. fluorescens increased nitrogen contents in seeds also, application of cobalt increased nitrogen content of seed and as cobalt concentration increased nitrogen content increased. Cobalt enhance total $\mathrm{N}$ accumulation (Vanek and Knob, 1997 and Nadia Gad, 2006), Seed inoculation with Pseudomonas strains of two chickpea cultivar significantly increased plant N contents (Goel et al., 2002). Pseudomonas could stimulate growth directly through production of growth hormones like indole acetic acetic, phosphatesolubilization and uptake of iron, whereas indirect mechanisms include check on phytopathogens by the release of $\mathrm{HCN}$, antibiotics and siderophores (O'Sullivan and O'Gara, 1992). Both of P. fluorescens and cobalt foliar application enhanced nitrogen fixation process by Bradyrhizobium where cobalt application played a greater role higher than Pseudomonas inoculation. P.flouresence and cobalt foliar application $(20 \mathrm{ppm})$ as interaction treatment gave the maximum nitrogen, phosphorus and potassium contents in seed being $(4.7 \%$ and $4.83 \%)$ and $(0.63 \%$ and $0.69 \%$ ) and $(1.23 \%$ and $1.35 \%)$ for nitrogen, phosphorus and potassium in first and second growing seasons respectively. Both of P.flouresence inoculation and cobalt application gave synergistic effect and enhanced mineral uptake and their metabolism in plant. The second growing season showed higher enhancement effect than the first growth season, these results are in agreement with those reported by ( Khalid et al., 2010).

TABLE 8. Effect of biofertilization and Cobalt application on some minerals contents of seeds.

\begin{tabular}{|l|c|c|c|c|c|c|c|}
\hline \multirow{3}{*}{ Treatments } & \multicolumn{7}{|c|}{$\mathbf{1}^{\text {st }}$ season } \\
\cline { 2 - 8 } & \multicolumn{2}{|c|}{ Macronutrients \% } & \multicolumn{3}{c|}{ Micronutrients (ppm) } \\
\cline { 2 - 8 } & $\mathbf{N}$ & $\mathbf{P}$ & $\mathbf{K}$ & $\mathbf{Z n}$ & $\mathbf{M n}$ & $\mathbf{F e}$ & $\mathbf{C u}$ \\
\hline Control & 3.8 & 0.53 & 1.08 & 12.6 & 14.9 & 26.53 & 10.84 \\
\hline Ps & 3.92 & 0.55 & 1.1 & 16.2 & 16 & 31.3 & 11.6 \\
\hline Co 5ppm & 4.06 & 0.54 & 1.12 & 12.73 & 15.5 & 25.1 & 11 \\
\hline Co 10ppm & 4.15 & 0.57 & 1.5 & 14.5 & 15.9 & 24.3 & 11.28 \\
\hline Co 20ppm & 4.2 & 0.58 & 1.18 & 16 & 16.7 & 22 & 11.9 \\
\hline Ps+Co5ppm & 4.36 & 0.6 & 1.19 & 16.8 & 17.3 & 34.6 & 13.8 \\
\hline Ps+Co10ppm & 4.5 & 0.61 & 1.2 & 18.6 & 17.8 & 36.1 & 14.7 \\
\hline Ps+Co20ppm & 4.7 & 0.63 & 1.23 & 20.2 & 18 & 37 & 16.2 \\
\hline L.S.D at 5\% & 0.12303 & 0.06418 & 0.17814 & 0.52187 & 0.6428 & 0.87622 & 0.6274 \\
\hline \multicolumn{1}{|c|}{ Control } & 3.92 & 0.55 & 1.11 & 13.8 & 15.6 & 27 & 11.2 \\
\hline \multicolumn{1}{|c|}{$\boldsymbol{P s}$} & 4.16 & 0.58 & 1.13 & 16.8 & 16.8 & 33 & 12.1 \\
\hline Co 5ppm & 4.22 & 0.56 & 1.16 & 14.2 & 16.1 & 24.5 & 11.8 \\
\hline Co 10ppm & 4.36 & 0.59 & 1.17 & 16.4 & 16.4 & 23.6 & 12.5 \\
\hline Co 20ppm & 4.39 & 0.61 & 1.2 & 17.1 & 18 & 21.5 & 13.4 \\
\hline Ps+Co5ppm & 4.48 & 0.63 & 1.24 & 18 & 17.6 & 35 & 15.1 \\
\hline Ps+Co10ppm & 4.65 & 0.67 & 1.31 & 20.2 & 18 & 36.7 & 16.9 \\
\hline Ps+Co20ppm & 4.83 & 0.69 & 1.35 & 22.6 & 18.6 & 37.2 & 17.8 \\
\hline L.S.D at 5\% & 0.030802 & 0.02523 & 0.07853 & 0.2609 & 0.876911 & 1.06875 & 0.20296 \\
\hline
\end{tabular}

Egypt. J. Soil Sci. 53, No. 4 (2013) 
Concerning micronutrients $(\mathrm{Fe}, \mathrm{Zn}, \mathrm{Mn}$ and $\mathrm{Cu}$ ) data recorded in Table 8 showed the same trend as macronutrients $(\mathrm{N}, \mathrm{P}, \mathrm{K})$, where combined application of cobalt $20 \mathrm{ppm}$ with P.flouresence inoculation in mixed treatment gave the highest response and superiority of micronutrients contents in seeds being (10.2, 18.1,37and 16.2) for $\mathrm{Zn}, \mathrm{Mn}, \mathrm{Fe}$ and $\mathrm{Cu}$ in first season and (11.3,18.6,37.2 and 17.8) for second season. Cobalt significantly increased the content of N,P,K,Mn and $\mathrm{Zn}$ as well as chemical contents ( Nadia Gad, 2012).

\section{Effect of biofertilization and Cobalt application on cobalt content in plant and} seed

Cobalt is essential for symbiotic nitrogen fixation by legumes, it is part of cobalmin (vitamine B12and its derivatives) (Nadia Gad, 2006, Mohamed et al., 2011 and Weisany et al., 2013), thus it is important to evaluate cobalt contents in plant and seeds. Also, data showed in Fig. 1 (A and B) confirmed the previous findings where inoculation with $P$. fluorescens increased the uptake of cobalt and related directly with increasing the concentration of applied cobalt. The interaction treatment between $P$. fluorescens and cobalt foliar application $(20 \mathrm{ppm})$ exhibited the maximum cobalt contents in plant and seed being 0.49 and 3.89 for first season and 0.54 and 4.17 for second season, respectively.

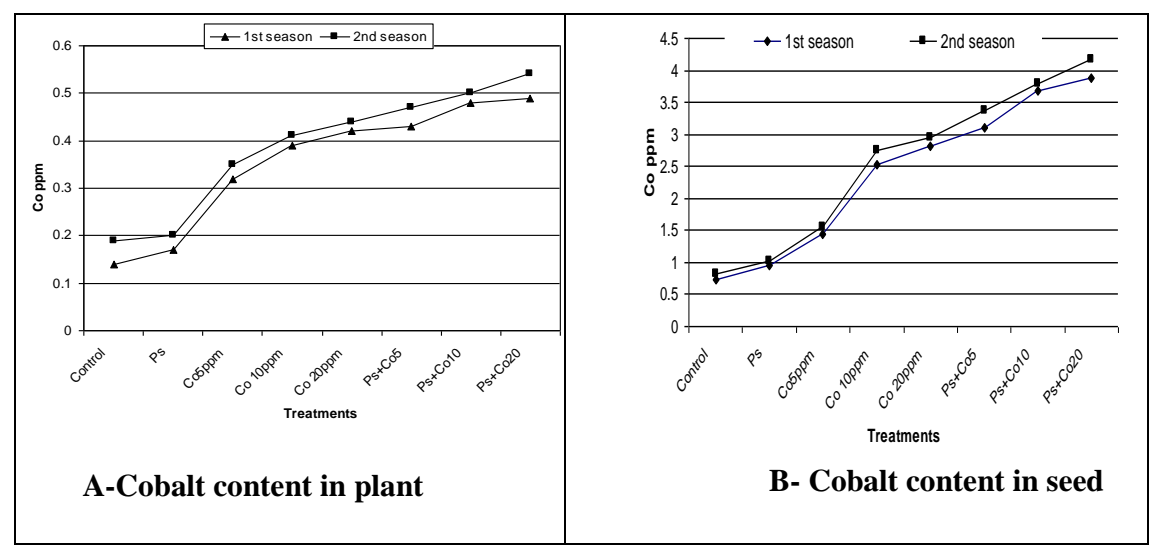

Fig. 1. Cobalt content in seed and plant.

It has been noticed that, there were a gradually increasing in cobalt by adding each of $P$. fluorescens and cobalt $(5,10,20 \mathrm{ppm})$ and the interaction between the abovementioned treatments respectively. Cobalt played an important role in increasing macro and micronutrient contents and promoted many developmental process like stem coleoptiles elongation, leaf expansion and bud development as reported by Abd El Moez and Nadia Gad (2002) and Weisany et al. (2013).

Although the competition between cobalt and iron contents in plant and seeds, the inoculation with P.flouresence may increase the iron content in plant and seeds due to siderophore formation. This is agrees with (Nadia Gad, 2006, Nadia Gad, 2012, Mohamed et al., 2011 and Gomaa \& Magda, 2007). 
Effect of biofertilization and Cobalt application on nodulation and its efficiency

Data presented in Table 9 clearly showed that, biofertilization with P.flouresence in the presence of Bradyrhizobium spp. as base treatment and cobalt foliar application with different concentrations(5,10 and $20 \mathrm{ppm})$ had a significant promoting effect on nodule number/plant, fresh and dry weights of nodules, nitrogenase activity and leghaemoglobin content compared with control. The interaction treatment with P.flouresence and Cobalt 20ppm foliar application gave greatest increase in the aforementioned parameters for nodulation and its efficiency (Table 9). The positive response increase as cobalt concentration increased from 5,10 and $20 \mathrm{ppm}$ in the presence of P.flouresence inoculation as mixed treatment higher than application of cobalt concentration or P.flouresence inoculation alone as single treatment that confirmed the presence of synergistic effect in their action on the studied parameters. These results are in harmony with those obtained by Abd El moez and Nadia Gad (2002) who reported that the addition of cobalt improved nodule formation process, number of root nodule, leghaemoglobin content, essential constituent of vit B12 which is important for root nodule production and nitrogense activity. Also, these results are in a good agreement with those found by Tenywa ( 2003 ) and Vanek \& knop (1997) and Nadia Gad (2006). The inoculation of groundnut with PGPR like Pseudomonas sp. enhanced growth, nodule and yield (Anandaraj and Leema, 2010). Also, Andrade et al. (1998) reported that P.flouresence enhanced nodulation by Rhizobium fourfold while the nodule produced were much large and strongly pigmented (Pink) as compared with other treatments.

TABLE 9. Effect of biofertilization and Cobalt application on nodulation and its efficiency.

\begin{tabular}{|c|c|c|c|c|c|}
\hline \multirow[b]{2}{*}{ Treatments } & \multicolumn{5}{|c|}{$1^{\text {st }}$ season } \\
\hline & $\begin{array}{c}\text { No.nodule/ } \\
\text { plant }\end{array}$ & $\begin{array}{c}\text { Fw.nodule } \\
(\text { gm) }\end{array}$ & $\begin{array}{c}\text { DW.nodule } \\
\text { (gm) }\end{array}$ & $\begin{array}{l}\text { Nitrogenase } \\
\mu \text { mole } \mathrm{C}_{2} \mathrm{H}_{2}\end{array}$ & $\begin{array}{c}\text { Leg.haemo } \\
\text { mg/g fresh } \\
\text { nodule }\end{array}$ \\
\hline Control & 4 & 30.4 & 11.2 & 16.93 & 5.2 \\
\hline$P s$ & 5 & 37.1 & 13.4 & 17.2 & 5.7 \\
\hline Co 5ppm & 5 & 34.8 & 12.1 & 18.53 & 5.3 \\
\hline Co 10ppm & 6 & 42.3 & 14.8 & 19.1 & 6 \\
\hline Co 20ppm & 7 & 48 & 16.5 & 19.7 & 6.2 \\
\hline Ps+Co5ppm & 7 & 51 & 17.81 & 20.4 & 6.6 \\
\hline Ps+Co10ppm & 8 & 56 & 20.2 & 20.9 & 7 \\
\hline Ps+Co20ppm & 9 & 63 & 21.7 & 21.3 & 7.3 \\
\hline L.S.D at $5 \%$ & 0.14989 & 1.2381 & 0.16203 & 0.15015 & 0.90975 \\
\hline \multicolumn{6}{|c|}{$2^{\text {nd }}$ season } \\
\hline Control & 6 & 39.61 & 14.3 & 18.81 & 5.6 \\
\hline$P s$ & 6 & 44.2 & 15.6 & 19.2 & 6.1 \\
\hline Co 5ppm & 6 & 48.1 & 15.8 & 19.27 & 5.9 \\
\hline Co 10ppm & 8 & 55 & 19.3 & 20.3 & 6.3 \\
\hline Co 20ppm & 8 & 56.4 & 19.82 & 20.51 & 6.4 \\
\hline Ps+Co5ppm & 9 & 61 & 20.5 & 21.94 & 6.8 \\
\hline Ps+Co10ppm & 9 & 64 & 22.3 & 22.35 & 7.2 \\
\hline Ps+Co20ppm & 11 & 71 & 24.6 & 24.8 & 7.5 \\
\hline L.S.D at $5 \%$ & 1.0635 & 1.3892 & 0.215001 & 0.69901 & 0.27368 \\
\hline
\end{tabular}

Egypt. J. Soil Sci. 53, No. 4 (2013) 
Effect of biofertilization and Cobalt application on microbial activity in Guar rhizosphere

A-Total microbial counts

Initial total microbial counts in New valley soil was $34 \times 10^{5} \mathrm{cfu} / \mathrm{gm}$ dry soil. Data in Table 10 showed that the counts tended to increase with all treatments refer to control. Total microbial counts proved an increase in second cut higher than first cut followed by harvesting in both growing seasons. Also, interaction treatment between P.flouresence inoculation and cobalt foliar application 20ppm produced the highest total microbial counts as compared with other treatments and control being $\left(91 \times 10^{5}\right.$ and $98 \times 10^{5} \mathrm{cfu} / \mathrm{gm}$ dry soil) in $2^{\text {nd }}$ cut of first and second seasons respectively. these results agreed with Subba Rao (1988) and Abd El-Ghany et al. (1997).

\section{$\mathrm{B}-\mathrm{CO}_{2}$ evolution}

The generation of carbon dioxide $\left(\mathrm{CO}_{2}\right)$ was determined as an indication of the biological activity in plant rhizosphere. Results in Table 10 clearly showed that mixed treatment with P.fluorescens inoculation and cobalt foliar application (20ppm) gave higher rate of $\mathrm{CO}_{2}$ evolution being 45 and $98 \mathrm{mgCO}_{2} / 100 \mathrm{~g}$ dry soil/24 hr than all other treatments in $2^{\text {nd }}$ cut of first and second season respectively. Data of $\mathrm{CO}_{2}$ evolution were almost in harmony with those of total microbial counts discussed before.These results agreed with (Visser and Dennis, 1992).

\section{C- Pseudomonas counts}

The initial Pseudomonas counts in new valley were $8.3 \times 10^{2} \mathrm{cfu} / \mathrm{gm}$ dry soil.Data recorded in Table10 proved a marked increase in Pseudomonas counts in first and second season. The increase in Pseudomonas counts was in second season higher than first one and the increase was in second cut higher than first cut but decreased at harvest. The counts under interaction treatment of P.flouresence with cobalt foliar application (20ppm) recorded the highest counts being $31 \times 10^{2}$ and $34 \times 10^{2}$ cfu/gm dry soil in second $\left(2^{\text {nd }}\right)$ cut of first and second season respectively.The highest increase in Pseudomonas counts were obtained by using the interaction treatment with cobalt (20ppm) and P.flouresence inoculation followed by P.flouresence inoculation treatment and cobalt foliar application treatments $(5,10,20 \mathrm{ppm})$ respectively. The promoting effect due to application of P.flouresence not only due to production of organic acid and siderophore which increase the availability of iron uptake but also to the production of plant growth promoting substances and antimicrobial substances as well which increase soil fertility, microbial communities and plant growth (Yadav et al., 2007).

Anandaraj and Leema (2010) confirmed that, combined inoculation increased the population of total bacteria, Rhizobium sp.and Pseudomonas fluorescens over uninoculated control indicating the ability of the introduced microorganisms to establish themselves in the rhizosphere. Cobalt is an essential element for growth of Bradyrhizobium spp. on root nodules and to synthesize vitamin B12 which required for the microorganisms fixing nitrogen in nodules (Nadia Gad, 2012). 
TABLE 10. Effect of biofertilization and Cobalt on microbial activity in Guar rhizosphere.

\begin{tabular}{|c|c|c|c|c|c|c|c|c|c|}
\hline \multirow{3}{*}{ Treatments } & \multicolumn{9}{|c|}{$\mathbf{1}^{\text {st }}$ season } \\
\hline & \multicolumn{3}{|c|}{$\mathrm{TC} \times 10^{5} \mathrm{cfu} / \mathrm{gm}$ dry soil } & \multicolumn{3}{|c|}{$\begin{array}{c}\mathrm{CO}_{2} \mathrm{mgCO}_{2} / 100 g \text { dry } \\
\text { soil } / 24 \mathrm{hr}\end{array}$} & \multicolumn{3}{|c|}{ Ps $\times 10^{2} \mathrm{cfu} / \mathrm{gm}$ dry soil } \\
\hline & $1^{\text {st }}$ cut & $2^{\text {nd }} \mathrm{cut}$ & Harv. & $1^{s t}$ cut & $2^{\text {nd }}$ cut & Harv. & $1^{\text {st }}$ cut & $2^{\text {nd }}$ cut & Harv. \\
\hline Control & 42 & 61 & 56 & 18.6 & 23.1 & 21 & 11.6 & 13.2 & 12.9 \\
\hline$P S$ & 53 & 75 & 69 & 26.2 & 39 & 33 & 17 & 29 & 21.26 \\
\hline Co 5ppm & 45 & 67 & 61 & 19.8 & 27 & 24 & 12 & 14.8 & 14.1 \\
\hline Co 10ppm & 51 & 74 & 63 & 22.4 & 31 & 25 & 13.1 & 16.5 & 15.3 \\
\hline Co 20ppm & 54 & 79 & 68 & 24.9 & 35 & 28 & 14.5 & 17.3 & 15.8 \\
\hline Ps+Co5 & 60 & 83 & 74 & 27.6 & 41 & 34 & 19.3 & 26.1 & 23.6 \\
\hline Ps+Co10 & 63 & 89 & 77 & 29 & 43 & 38 & 22 & 29 & 27.59 \\
\hline $\mathrm{Ps}+\mathrm{Co} 20$ & 64 & 91 & 81 & 30 & 45 & 41.3 & 24 & 31 & 12.9 \\
\hline $\begin{array}{l}\text { L.S.D at :Bio } \\
\text { Cut Interaction }\end{array}$ & \multicolumn{3}{|c|}{$\begin{array}{c}1.1608 \\
0.71087 \\
1.5\end{array}$} & \multicolumn{3}{|c|}{$\begin{array}{c}0.778796 \\
0.47693 \\
0.6754\end{array}$} & \multicolumn{3}{|c|}{$\begin{array}{c}0.5281 \\
0.3234 \\
0.31044\end{array}$} \\
\hline \multicolumn{10}{|c|}{$2^{n d}$ season } \\
\hline Control & 47 & 64 & 59 & 19.4 & 24 & 21.5 & 11.9 & 13.8 & 13.1 \\
\hline$P s$ & 55 & 83 & 76 & 28 & 40 & 34.3 & 19.4 & 31 & 23 \\
\hline Co 5ppm & 48 & 69 & 64 & 21 & 29 & 25 & 13.8 & 16 & 15.2 \\
\hline Co 10ppm & 54 & 77 & 68 & 24 & 34 & 26.8 & 14.2 & 17.4 & 15.9 \\
\hline Co 20ppm & 57 & 80 & 71 & 27.4 & 38 & 29 & 15.3 & 18.6 & 16.4 \\
\hline $\mathrm{Ps}+\mathrm{Co} 5$ & 62 & 88 & 78 & 31 & 42 & 37 & 21.8 & 28 & 25.71 \\
\hline Ps+Co10 & 66 & 94 & 79 & 35 & 47 & 42.8 & 25 & 30 & 28 \\
\hline $\mathrm{Ps}+\mathrm{Co} 20$ & 73 & 98 & 84 & 37 & 49 & 44.7 & 27 & 34 & 30.2 \\
\hline $\begin{array}{l}\text { L.S.D at } 5 \% \text { : Bio } \\
\text { Cut } \\
\text { Interaction }\end{array}$ & \multicolumn{3}{|c|}{$\begin{array}{c}1.133651 \\
0.69422 \\
1.43056\end{array}$} & \multicolumn{3}{|c|}{$\begin{array}{c}1.044750 \\
0.63978 \\
1.215\end{array}$} & \multicolumn{3}{|c|}{$\begin{array}{l}1.1849 \\
1.8493 \\
0.2991\end{array}$} \\
\hline
\end{tabular}

$\begin{array}{lrl}\text { Tc: total microbial count. } & \text { Co: Cobalt. } & \text { Ps: Pseudomonas fluorescens. }\end{array}$

\section{Conclusion}

It could reasonably concluded from the abovementioned results that biofertilization with P.flouresence showed a powerful effects on the growth, yield of guar and microbial community in rhizosphere of inoculated plant. Cobalt foliar application resulted in enhancement effect toward aforementioned parameters within range used in this study. interaction treatment between P.flouresence inoculation and cobalt foliar application (20ppm) resulted in a maximum benefits toward growth parameters, yield and its components, nutritional status, nodulation characters and microbial activity in rhizosphere of guar plant as compared with control (Brady-rhizobium spp.only).

\section{References}

Abd El-Ghany, B.F., Khalil, K.W., El-Sersawy, M.M. and Awadallah, S.Y. (1997) Improvement of Wadi Sudr soil properties using modern bio-organic techniques and their effects on desertification combat and barley production. Desert Ins. Bull. Egypt. 47(1): 69-100.

Abd El-Moez, M.R. and Nadia, Gad (2002) Effect of organic cotton compost and cobalt application on cowpea plants growth and mineral composition. Egypt. J. Appl. Sci. 17: 426-440.

Egypt. J. Soil Sci. 53, No. 4 (2013) 
Ahmad, J. (2008) Effect of different levels of phosphorus and potassium on growth, forage yield and quality of cluster bean. M.Sc.Thesis, Dept. Agron., Univ. of Agric. Faisalabad, Pakistan.

Aml, E.A. El-Saidy and Abd El-Hai, K.M. (2011) Alleviation of peanut seed deterioration during storage using biotic and abiotic agents. Res. J. Seed Sci.: 1-13.

Anandaraj, B. and Leema Rose Delapierre, A. (2010) Studies on influence of bioinoculants (Pseudomonas fluorescens, Rhizobium sp., Bacillus megaterium) in green gram. J. Biosci Tech. 1 (2): 95-99.

Anderson, J. P. E. (1982) Soil respiration. In: "Methods of Soil Analysis", A. L. Page, R. H. Miller and D. R. Keeney (Ed.), part 2, $2^{\text {nd }}$ ed., pp.837-871, Madison, Wisc.:ASA and SSSA.

Andrade, G., De Leij, F.A.M. and Lynch, J.M. (1998) Plant mediated interactions between Pseudomonas fluorescens, Rhizobium leguminosarum and arbuscular mycorrhizae on pea. Letters in Applied Microbiology 26: 311-316.

Ayub, M., Tahir, M., Ather Nadeem, M., Arif Zubair, M., Tariq, M. and Ibrahim, M. (2012) Effect of Nitrogen Applications on Growth, Forage Yield and Quality of Three Cluster Bean Varieties. Pak. J. Life Soc. Sci. 8(2): 111-116.

Barrow, G.L. and Velthan, R.K.A. (1993) "Cown \& Steel's", Mannual for the identification of medical bacteria. Cambridge Univ. Press.

Basak, B.B. and Biswas, D.R. (2008) Influence of potassium solubilizing microorganism (Bacillus mucilaginous) and waste mica on potassium uptake dynamics by Sudan grass (Sorghum vulgare Pers) grown under two Alfisols. Plant and Soil 317, 235-255.

Bergey's Manual of Systemic Bacteriology (1984) Vol. 1, N.R., Krieg and J.G., Holt (Ed.). Genus Azospirillum. pp. 94-103 and Genus Azotobacter pp. 225-229.Vol(II) p. 1104-1139. Sneath, Ph.D.(ed.). Genus Bacillus subtilis. Williams, Wilkins, Baltimore, USA.

Bergey's Manual of Determinative Bacteriology (1994) G . John, Hol, Noel R. Kriey, H.A., Peter Sneath, T. James, T.Staley and Williams (Ed.), $9^{\text {th }}$ ed., Williams and Wilkins, Baltimore, London.

Boruah, H., Rabha, B.K., Saikia, N. and Kumar, B. S. D. (2003) Fluorescent Pseudomonas influences palisade mesophyll development and spatial root development in Phaseolus vulgaris: Plant and Soil 256(2): 291-301.

Brokwell, J. and Bottmely, P.J. (1995) Recent advances in inoculant technology and prespects for the future. Soil Biology and Biochemistry 27: 683-697.

Burris R.H. and Roberts, G.P. (1993) Biological nitrogen fixation. Annual Review of Nutrition 13: 317-335.

Compant, S., Clement, C. and Sessitch, A. (2010) Plant growth-promoting bacteria in the rhizo- and endosphere of plants: Their role, colonization, mechanisms involved and prospects for utilization. Soil Biology and Biochemistry 42: 669-678. 
Cottenie, A., Verloo, M., Kiekens, L., Velgh, G. and Camerlynck, R. (1982) Chemical analysis of plant and soil. Chemical Analysis of Plants and Soils. pp. 44-45, State Univ.,Ghent, Belgium.

DeFreitas, J.R., Banerjee, M.R. and Germida, J.J. (1997) Phosphate solubilizing rhizobacteria enhance the growth and yield but not phosphorus uptake of Canola (Brassica napus L.). Biol. Fertil. Soils 24: 358-364.

Dua, S. and Sindhu, S.S. (2012) Effectiveness of rhizosphere bacteria for control of root rot disease and improving plant growth of wheat (Triticum aestivum L.). Journal of Microbiological Research 2: 26-35.

El-Sayed, S.A.M. (1997) Influence of salinity on growth, yield, nutrient uptake and biological nitrogen fixation in guar. Egypt. J. Agric. Res. 75(1).

El-Sheikh, E.A.E. and Ibrahim, K.A. (1999) The effect of Bradyrhizobium inoculation on yield and seed quality of guar (Cyamopsis tetragonoloba L.). Food Chemistry 65:183-187.

Evan, H.J. and Kliwer, M. (1964) Vitamin B compounds in relation to the requirements of cobalt for higher plants and nitrogen fixing organisms. Annals of New York Academic Science 2: 732-755.

Farag, A.A. and Abdel-Lateef, E.M. (1997) Effect of NPK combination on growth and yield of guar (Cyamopsis tetragonloba L.) taub. Al AzharJ. Agric. Sci. 23:15-25.

Francios, L.E., Donowan,T.J. and Mass, E.V. (1999) Salinity effects on emergence vegetative growth and seed yield of guar. Agron.J. 82: 587-592.

Gaballah, M.S. and Gomaa, A.M. (2005) Interavtive effect of Rhizobium inoculum, sodium benzoate and salinity on performance and oxidative stress in teo faba bean varities. Int. J. Agric. Biol. Pakistan 7: 495-498.

Gadalla, A., Elhassan, Migdam, E., Abdelgani, Awad, G.O., Somaya, S. Mohamed and Belgees, S.A. (2010) Potential prodution and Application of Biofertilizers in Sudan. Pakistan Journal of Nutrition 9 (9): 926-934.

Garg, B.K. and Burman, U., Kumar, D. and Singh, N.B. (2002) In: "Guar in India", pp. 63-84, Scientific Publishers, Judhpur.

Garthright, W. E. (1993) Bias in the logarithm of microbial density estimates from serial dilutions. Biom. J. 3: 299-314.

Goel, A. K., Sindhu, S. S. and Dadarwal, K. R. (2002) Stimulation of nodulation and plant growth of chickpea (Cicer arietinum L.) by Pseudomonas spp. antagonistic to fungal pathogens: Biology and Fertility of Soils 36(6): 391-396.

Gomaa, A.M. and Magdaa, H.M. (2007) Application of bio-organic agriculture and its effect on guar (Cyamopsis tetragonoloba L.) root nodules, forage, seed yield and yield quality. World J.of Agric.Sci. 3(1): 91-96. 
Gurusaravanan, P., Vinoth, S., Roy, J., Siva, G., Boopala, B. N., Pandiyarajan, V. and Jayabalan, N. (2012) Evaluation of physiological, biochemical and enzymatic activity during accumulation of $\mathrm{CoCl}_{2}$ in Cyamopsistetragonoloba (L.) TAUB and its impact on protein profile. International Research Journal of Biotechnology 3(10): 198-206.

Haahtela, K., Wartiovaara, T. and Sundman, V. (1981) Root-associated $\mathrm{N}_{2}$ fixation (acetylene reduction) by Enterobacteriaceae and Azospirillum strains in cold- climate spodsols. Appl. Environ. Microbiol. 41: 203-206.

Jangu, O.P. and Sindhu, S.S. (2011) Differential response of inoculation with indole acetic acid producing Pseudomonas sp. in green gram (Vigna radiata L.) and black gram (Vigna mungo L.). Microbiology Journal 1: 159-173.

Jarlier, V., Fosse, T. and Philipon, A. (1996) Antibiotic susceptibility in aerobic Gramnegative bacilli isolated in intensive care units in 39 French teaching hospitals (ICU study) Intensive Care Mod. 22: 1057-1065.

Jayakumar, K. and Vijayarengan, P. (2006) Influence of cobalt on seed germination and seedling growth of Vigna mungo (L.) Hepper. Plant Arch. 6: 681-682.

Jayakumar, K., Abdul Jaleel, C., Azooz, M.M., Vijayarengan, P., Gomathinayaga, M. and Panneerselvam, R. (2009) Effect of Different Concentrations of Cobalt on Morphological Parameters and Yield Components of Soybean. Global Journal of Molecular Sciences 4(1): 10-14.

Kaliyamoorthy, J., Rajesh, M., Sankar, G. K. and Vijayarengan, P. (2013) Cobalt Alters the Nodulation, Leg-Haemoglobin Content and Antioxidant Potential of Horse Gram (Dolichos biflorus). International Journal of Modern Biochemistry 2(1): 15-23.

Khalid, A.I., Kamal, H. S. and Abdalla, A.A. (2010) Influence of Inoculation with some Bradyrhizobium strains on yield attributes, seed proximate composition and minerals content of Guar (Cyamopsis tetragonoloba L.) Grown in Sudan. Australian J. of Basic and Applied Sciences 4(5): 808-816.

Lugtenberg, B. and Kamilova, F. (2009) Plant growth promoting rhizobacteria. Annual Review of Microbiology, 63: 541-556.

Malik, A. and Teuswal, R. (2000) Metal resistence in Pseudomonas strains isolated from soil treated with industrial wastewater. World J. Microbiol Biotechnol. 16:177-182.

Miller, R. (1998) Nitric-Perchloric Acid Wet Digestion in an Open Vessel. In: "Handbook of Reference Method for Plant Analysis Kalara", Ya (Ed.), pp.57-63, CRC Press, LLC,USA.

Mohamed, Hoda A. and Gomaa, A.M. (2005) Faba bean growth and green yield and its quality as influenced by the application of bio-organic farming system. J.Applied Sci. Res. Pakistan 1:380-385.

Mohamed, M.A., Elsherif, M.H., Amira, H., Nadia, G. and Sayed, G.S. (2011) Reducing N Doses by Enhancing Nodule Formation in Groundnut Plants via Co and Mo. Australian Journal of Basic and Applied Sciences 5 (12): 2568-2577. 
Meyer, J.R. and Linderman, R.G. (1986) Response of subterranean clover to dual inoculation with arbuscular mycorhizzal fungi and a plant growth promoting bacterium Pseudomonas putida. Soil Biology and Biochemistry 18:185-190.

Meyer, J. M., Azelvandre, P. and Georges, C. (1992) Iron metabolism in Pseudomonas: salicylic acid, a siderophore of Pseudomonas fluorescens CHAO. Biofactors. 4: 2327.

Murray, P. R., Baron, E. J., Jorgensen, J. H., Pfaller, M. A. and Yolken, R. H. (2003) "Manual of Clinical Microbiology", $8^{\text {th }}$ ed., ASM, Washington, D.C.

Gad, Nadia (2006) Increasing the efficiency of nitrogen fertilization through cobalt application to Pea plant. Research Journal of Agriculture and Biological Sciences 2(6): 433-442.

Nadia Gad (2012) Role and Importance of Cobalt Nutrition on Groundnut (Arachis hypogaea). Production World Applied Sciences Journal 20 (3): 359-367.

Nasef, M.A., Abd El-Hameed, A.M., Salem, H.M. and Abd El-Hamide, A.F. (2008) Efficiency of applied rates and methods of cobalt on growth, yield and elemental composition of peanut plants grown on a sandy soil. Annals of Agricultural Science, Moshtohor 42(2): 851-860.

Nautiyal, C.S. (1999) An efficient microbiological growth medium for screening phosphate solubilizing microorganisms. FEMS Microbiology Letters. 170: 265- 270.

O'Sullivan, D.J. and O'Gara, F. (1992) Traits of fluorescent Pseudomonas spp., involved in suppression of plant root pathogens. Microbiol. Rev. 56: 662-676.

Page, A.L., Miller, R.H. and Keeney, D.R. (1982) "Methods of Soil Analysis", $2^{\text {nd }}$ ed., American Society of Agronomy, Madison, WI., USA.

Parmar, P. and Sindhu, S.S. (2013) Potassium solubilization by rhizosphere bacteria: influence of nutritional and environmental conditions. Journal of Microbiological Research 3: 25-31.

Pramer, D. and Schmidt, E.L. (1964) "Experimental Soil Microbiology”, Burgess Pub.Co., Minnesota,U.S.A.

Reeves, M., Pine, L., Neilands, J. B. and Bullows, A. (1983) Absence of siderophore activity in Legionella sp. grown in iron deficient media. Journal Bacteriology 154: 324-329.

Rizzolo, A.C., Baldo, J. and Polesello, A. (1993) Application of high performance liquid chromatography to the analysis of niacin and biotin in Italian almond cultivars. $J$. of Chromatoghraphy 553(1-2).

Scholhorn, R. and Burris, R. H. (1967) Acetylene as a competitive inhibitor of $\mathrm{N}_{2}$ fixation. Proc. Natl. Acad. Sci. USA 58: 213-216.

Sindhu, S.S., Jangu, O.P. and Sivaramaiah, N. (2010) Genetic engineering of diazotrophic bacteria to improve nitrogen fixation for sustainable agriculture. In:

Egypt. J. Soil Sci. 53, No. 4 (2013) 
“Biotechnology: Emerging Trends", R.Z. Sayyed and A.S. Patil (Ed.), pp. 73-112, Scientific Publishers, Jodhpur, India.

Sindhu, S.S., Verma, M.K. and Mor, S. (2009) Molecular genetics of phosphate solubilization in rhizosphere bacteria and its role in plant growth promotion. In: "Phosphate Solubilizing Microorganisms and Crop Productivity", M.S. Khan and A. Zaidi (Ed.), pp. 199-228, Nova Science Publishers, USA.

Schinner, F., Oninger, R., Kandeler E. and Margesin, R. (1996) "Methods in Soil Biology", Springer-Verlag, Berlin Heidelberg-Jerman.

Snedecor, G.W. and Cochran, W.G. (1990) "Statistical Methods”, Iowa State, Univ. Press, Ames, Iowa, USA.

Staley,T.E., Lawerence, E.G. and Nale, E.L. (1992) influence of a plant growth promoting Pseudomonad and vesicular arbascular mycorrhizal fungus on alfalfa and birdsfoot trefoil growthand nodulation. Biology and Fertility of Soils 14:175-180.

Stockwell, V.O. and Stack, J.P. (2007) Using Pseudomonas spp. for integrated biological control. Phytopathology 97: 244-249.

Subba Rao, N.S. (1988) "Biofertilizers in Agriculture", Oxford and IBH Publishing Co., pp. 6-9, 16-22, 77-92 and 142-160, New Delhi, Bombay, Calcutta, India.

Tenywa, J.S. (2003) Influence of cobalt fertilization on symbiotic nitrogen fixation indicators in an oxisolin Uganda. African Crop Sci. J. 5: 87 - 92.

Tran, G. (2013) Guar (Cyamopsis tetragonoloba) forage, seed and meal. Feedipedia.Org., A programme by INRA, CIRAD, AFZ and FAO.

Vanek, V. and Knop, K. (1997) The effect of cobalt and molybdenum on nitrogen fixation in peas. Rostlinna Vyroba 18: 521-529.

Vijayarengan, P., Abdul Jaleel, C., Chang-Xing, Z., Jayakumar, K. and Azooz, M.M. (2009) Biochemical Variations in Groundnut under Cobalt Applications. Global Journal of Molecular Sciences 4(1): 19-22.18.

Visser, S. and Dennis, P. (1992) Soil biological criteria as indications of soil quiantity:Soil microorganisms. American J. of Alternative Agriculture 7: 33-37.

Weisany, W., Yaghoub, R. and Kaveh, H. A. (2013) Role of Some of Mineral Nutrients in Biological Nitrogen Fixation Bull. Env. Pharmacol. Life Sci. 2(4): 77-84.

Wilson, D.O. and Reiesenauer (1963) Determination of leghaemoglobin in legume nodule. Analy. Biochem. 6: 27-30.

Welbaum, G., Sturz, A.V., Dong, Z. and Nowak, J., (2004) Fertilizing soil microorganisms to improve productivity of agroecosystems. Critical Reviews in Plant Sciences 23: 175-193.

Yadav, E., Pathak, D. V., Sharma, S. K., Kumar, M. and Sharma, P. K. (2007) Isolation and characterization of mutants of Pseudomonas maltophila PM-4 altered in 
chitinolytic activity and antagonistic activity against root rot pathogens of clusterbean (Cyamopsis tetragonoloba). Indian J. of Microbiology 47: 64-71.

Young, S.R. (1983) Recent advances on cobalt human nutrition, Victoria Pochvoredeniyc 3: $59-62$.

(Received 26/ 9/2013;

$$
\begin{aligned}
& \text { دراسة تأثير التسميد الحيوى والكوبلت على النمو وانتاجية نبات } \\
& \text { الجوار تحت ظروف الوادى الجديد } \\
& \text { عمرو محمود عبد الجواد } \\
& \text { قسم خصوبة وميكروبيولوجيد الجوا الارا ضى ـ مركز بحوث الصحراء ـ القاهرة ـ }
\end{aligned}
$$

لبيان تأثبر التسميد الحيوى باستخدام السيدوموناس فلوريسنس والكوبلت على إنى

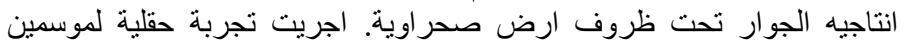

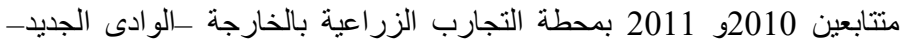

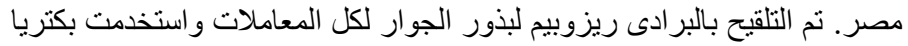

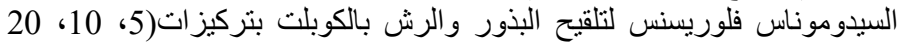

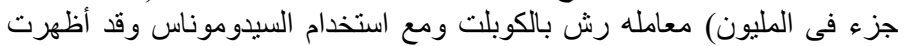

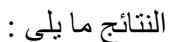

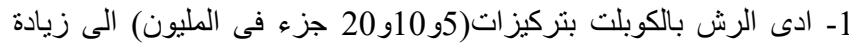

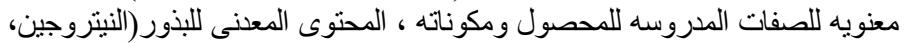

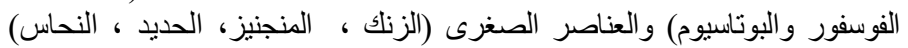

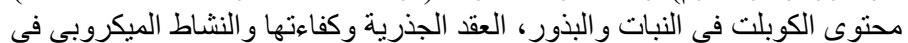

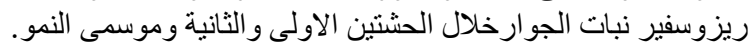

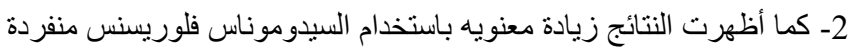

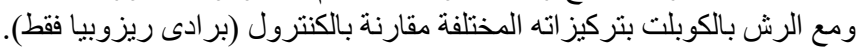

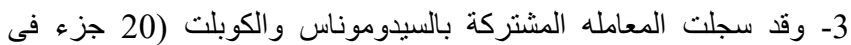

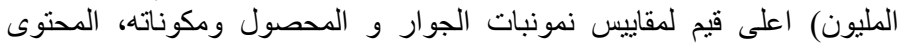

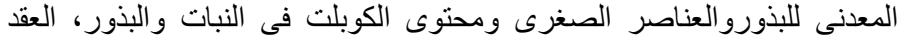

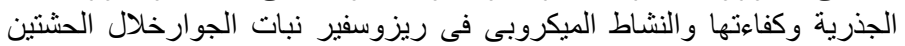

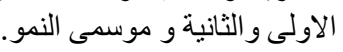

